\title{
STUDIES ON VIBRIO ALGINOLYTICUS INFECTION AMONG SOME RED SEA FISHES AT HURGHADA
}

\author{
MOHAMED RAAFAT ELSAYED ${ }^{1}$; AHMED ELSAYED OSMAN ${ }^{2}$; \\ ARAFAH M. EMAM ${ }^{3}$; MOHAMED ABD EL-AZIZ AHMED \\ ABD EL-GALIL ${ }^{1}$ AND HAITHAM HELMY SAYED ${ }^{4}$
}

${ }^{1}$ Fish Diseases and Management Department, Faculty of Veterinary Medicine, Sohag University, Sohag, 82524, Egypt.; mohamed.rafat2018@vet.sohag.edu.eg.; abdelgalil1997@yahoo.com

${ }^{2}$ Biochemistry Department, Faculty of Veterinary Medicine, Sohag

University, Sohag, 82524, Egypt.; ELsaid 80- bio@yahoo.com

${ }^{3}$ National Institute of Oceanography and Fisheries, Hurghada, Egypt.; arafah_emam@yahoo.com ${ }^{4}$ Microbiology Department, Faculty of Veterinary Medicine, Sohag University, Sohag, 82524, Egypt. haytham_adam@vet.sohag.edu.eg

Received: 2 August 2021; Accepted: 20 August 2021

\begin{abstract}
Bacteria are one of the most prevalent causes of morbidity and mortality among wild fishes. Vibrio alginolyticus ( $V$. alginolyticus) is a serious fish pathogen. This study was performed to investigate prevalence of $V$. alginolyticus infection among six species of Red Sea fishes at Hurghada city, Egypt through clinical and bacteriological examinations and to determine pathogenicity of the isolates and their antimicrobial susceptibilities. Therefore, a total number of 180 fish from these six fish species (30 fish of each species) were randomly collected from the Red Sea at Hurghada city during the period from October 2019 to March 2020 and subject to clinical and bacteriological examinations. Based on the morphological and biochemical characteristics of the isolates, 64 homogenous $V$. alginolyticus isolates were isolated and phenotypically identified from the examined fishes with prevalence of (26.7\%), (20\%), (63.3\%), (36.7\%), (23.3\%) and (43.3\%) among Lutjanus ehrenbergii (L. ehrenbergii), Lethrinus borbonicus (L. borbonicus), Siganus rivulatus (S. rivulatus), Rhabdosargus haffara ( $R$. haffara), Scarus ghobban (S. ghobban) and Cheilinus lunulatus (C. lunulatus) fishes respectively. Afterthat, representative isolates were cofirmed as $V$. alginolyticus by $16 \mathrm{~S}$ rRNA gene sequence and deposited in GenBank as V. alginolyticus MR-C17 (GenBank accession no. MW790239). The $V$. alginolyticus infected fishes exhibited skin dark coloration, scales loss, hemorrhages on several parts of the body surface, mouth, base of fins, abdomen, opercula and around the anal opening, eroded fins, ascites, swollen intestine and congestion or paleness of the internal organs espeially liver. Antimicrobial susceptibility testing of $V$. alginolyticus isolates revealed that they were sensitive to chloramphenicol, tetracycline, ciprofloxacin and ofloxacin and resistant to ampicillin, cephalothin, amikacin, streptomycin, cefotaxime, erythromycin, oxolonic acid, amoxicillin/clavulanic acid, tobramycin and clindamycin. Pathogenicity test revealed that $V$. alginolyticus MR-C17 was pathogenic to $R$. haffara with $80 \%$ mortalities in the experimentally infected fish which showed similar clinical signs and post-mortem (PM) lesions to thoes observed in the naturally infected fishes.
\end{abstract}

Keywords: Vibrio alginolyticus, infection, Red Sea fishes, Hurghada.

Corresponding author: Mohamed Abd El-Aziz Ahmed Abd El-Galil

E-mail address: abdelgalil1997@yahoo.com

Present address: Fish Diseases and Management Department, Faculty of Veterinary Medicine, Sohag University, Sohag, 82524, Egypt. 


\section{INTRODUCTION}

Fisheries represent an important sector of the Egyptian national income where fish production from natural resources is about $26.7 \%$ of the total Egyptian fish production (Hassan et al., 2019). Marine fishes represent the major investment choice for the national fishermen and become an important source of income in many developing countries (FAO, 2012). Red Sea is about $2250 \mathrm{~km}$ length and contains about 1166 fish species from 159 families (Bogorodsky and Randall, 2019). L. ehrenbergii, L. borbonicus, S. rivulatus, $R$. haffara, S. ghobban and C. lunulatus fish species are considered economically important Red Sea fishes in Egypt, so that they were investigated in this study.

Bacteria are the most prevalent cause of morbidity and mortality among wild fishes (Mohanty and Sahoo, 2007) and they were predominantly opportunistic pathogens. Vibriosis is one of the most prevalent and serious bacterial diseases affecting diverse marine fishes and shellfish (Liu et al., 2004) and generally referred to septicemic bacterial infection of both wild and farmed marine fishes. It is considered as a significant problem with severe economic losses in aquaculture industry worldwide (Mancuso et al., 2015). Vibrio alginolyticus was classified as one of the seven Vibrio fish pathogens (Austin and Austin, 1987) and was isolated from many marine fish species including silver sea bream (Sparus sarba), Gilthead sea bream (Sparus aurata) and cultured seabream (Sparus auratus L.) (Austin and Austin 2007), Siberian Sturgeon (Acipenser Baerii) (Costinar et al., 2010) and Bird wrasse fish (Gomphosus caeruleus) (Abd El-Galil and Hashem, 2012).
The $V$. alginolyticus infected fishes showed skin dark coloration, scales loss, hemorrhages on several parts of the body surface, mouth, base of fins, abdomen, opercula and around the anal opening, eroded fins, ascites and the PM findings were pale enlarged liver with hemorrhagic edge, congested kidney, congested enlarged spleen, enlarged gall bladder, ascetic fluid in the abdominal cavity and liquefaction of internal viscera. Particular attention should be taken to the zoonotic importance of $V$. alginolyticus due to possibility of its transportation from contaminated water and infected fish to human (Abd El-Galil and Hashem, 2012).

Accurate and rapid diagnosis of the bacterial diseases plays a great role in their successful control and treatment. Molecular techniques using 16S rRNA gene sequence alongside biochemical characteristics are rapid and accurate methods for microbial identification in the laboratory diagnosis (Buller, 2004).

The present work was performed to investigate $V$. alginolyticus infection among the Red Sea fish species previously mentioned at Hurghada city through clinical examination, bacteriological isolation, phenotypic and genotypic identification of the isolates and to determine pathogenicity of the isolates and their antimicrobial susceptibilities.

\section{MATERIALS AND METHODS}

\section{Ethical committee approval:}

All the procedures and protocols performed in this study were reviewed and approved by research ethics committee of Faculty of Veterinary Medicine, Sohag University, Egypt. 


\section{1- Study area and fish sampling:}

In this study, a total number of 180 fish from six different fish species (30 fish of each species) were randomly collected from the Red Sea at Hurghada city, Egypt during the period from October 2019 to March 2020. The collected fishes were transported immediately in small tank containing a suitable amount of sea water with continuous aeriation to an indoor aquarium in the National Institute of Oceanography at Hurghada for further studies. The examined fish species included L. ehrenbergii (Blackspot snapper), $L . \quad$ borbonicus (Snubnose emperor), $S . \quad$ rivulatus (Marbled spinefoot), $R$. haffara (Haffara seabream), $S$. ghobban (Blue-barred parrotfish) and C. lunulatus (Broomtail wrasse).

\section{2- Clinical and post-mortem examination:}

The fishes were examined clinically for detection of the external abnormalities or lesions then subject to PM examination for detection of any macroscopical lesions in the organs according to the protocol described by Schaperclaus (1992). Prior to dissection, live fishes samples were euthanized using tricaine methanesulfonate (Sigma-Aldrich) by immersion in $250 \mathrm{mg} / \mathrm{L}$ for 10 minutes following cessation of the opercular movement according to American Veterinary Medical Association guidelines on euthanasia (2007).

\section{3- Bacterial isolation and biochemical identification:}

Under aseptic conditions, samples were collected from the internal organs (liver, kidney and spleen) of the fishes by sterile bacteriological loop. The collected samples were inoculated into tryptone soya broth (TSB) (Oxoid, England) and incubated at $22^{\circ} \mathrm{C}$ for up to 24 hours.
Then, inocula from this broth were streaked onto tryptone soya agar (TSA) and Thiosulfate citrate bile salts sucrose agar (TCBS) (Oxoid, England) supplemented with $1.5 \% \quad \mathrm{NaCl}$ and incubated at $22^{\circ} \mathrm{C}$ for up to 48 hours (Noga, 1996). The recovered isolates were preserved at $-80^{\circ} \mathrm{C}$ in TSB supplemented with $25 \%$ glycerol and $1.5 \% \mathrm{NaCl}$ till further identification.

The suspected isolates were identified through assessment of their morphological characteristics, Gramstaining, motility test, cytochrome oxidase test using the standard laboratory methods described by Holt et al. (1994) and API 20E system (BioMerieux, France) according to manufacturer's instructions. The isolates were identified as $V$. alginolyticus according to criteria of Buller (2004).

\section{4- 16S rRNA gene sequence analysis:}

Bacterial DNA was extracted from the recovered isolates using Gene JET genomic DNA purification kit (Thermo Scientific, EU) according to the manufacturer's instructions and it was preserved at $-20^{\circ} \mathrm{C}$ till used. PCR was conducted to amplify the hypervariable segment of 16s rRNA (1500 bp) using the universal primers illustrated in table (1) (Frank et al., 2008) and MyTaq red mix (Bioline, UK). The reaction mixture of PCR was prepared in $50 \mu \mathrm{l}$ mixture according to mastermix manufacturer's instructions where it contained $25 \mu$ of mastermix, $2 \mu \mathrm{l}$ from each of forward and reverse primers, $4 \mu \mathrm{l}$ from the extracted DNA and $17 \mu \mathrm{l}$ of NucleaseFree Water. PCR reaction was conducted in a thermocycler (Applied Biosystems, USA) under PCR conditions illustrated in table (1) (Polz and Cavanaugh, 1998)

The amplicons (1500 base pairs) were 
purified and sequenced by 3500 Genetic Analyzer (Applied Biosystems, U.S.A.) at Solgent Co. Ltd (South Korea) using Sanger dideoxy sequencing technology. Sequences of the recovered isolates were analyzed using MEGA 7.0 software and were compared to those available at Gen
Bank database. Evolutionary distances were computed using maximum composite-likelihood method. Phylogenetic tree based on 16s rRNA gene sequences was reconstructed by the neighbor-joining method (Kumar et al., 2016).

Table 1: Oligonucleotide primers and PCR conditions uesd in the study to amplify 16s rRNA gene (1500 bp) of $V$. alginolyticus.

\begin{tabular}{|c|c|c|c|c|c|}
\hline \multirow{2}{*}{$\begin{array}{l}\text { Primers sequences } \\
\qquad\left(5^{`}-3^{`}\right)\end{array}$} & \multirow{2}{*}{$\begin{array}{c}\text { Primary } \\
\text { denaturation }\end{array}$} & \multicolumn{3}{|c|}{ PCR conditions (35 cycles) } & \multirow{2}{*}{$\begin{array}{c}\text { Final } \\
\text { extension }\end{array}$} \\
\hline & & Denaturation & Annealing & Extension & \\
\hline $\begin{array}{c}\text { F27 } \\
\text { AGAGTTTGATCCTGGC } \\
\text { TCAG } \\
\end{array}$ & \multirow{2}{*}{$\begin{array}{l}95^{\circ} \mathrm{C} \\
5 \mathrm{~min} .\end{array}$} & \multirow{2}{*}{$\begin{array}{l}94^{\circ} \mathrm{C} \\
1 \mathrm{~min} .\end{array}$} & \multirow{2}{*}{$\begin{array}{l}55^{\circ} \mathrm{C} \\
1 \mathrm{~min} .\end{array}$} & \multirow{2}{*}{$\begin{array}{c}72^{\circ} \mathrm{C} \\
1.5 \mathrm{~min}\end{array}$} & \multirow{2}{*}{$\begin{array}{c}72^{\circ} \mathrm{C} \\
10 \mathrm{~min} .\end{array}$} \\
\hline $\begin{array}{c}\mathbf{1 4 9 2 R} \\
\text { TACCTTGTTACGACTT } \\
\end{array}$ & & & & & \\
\hline
\end{tabular}

\section{5- Antimicrobial Susceptibility Testing:}

Antimicrobial susceptibility of $V$. alginolyticus isolates was determined by Kirby-Bauer disc diffusion method using (14) different antibiotics included ampicillin $(10 \mu \mathrm{g})$, amoxicillin/clavulanic acid $(30 \mu \mathrm{g})$, cephalothin $(30 \mu \mathrm{g})$, cefotaxime $(30 \mu \mathrm{g})$, streptomycin $(10 \mu \mathrm{g})$, amikacin $(30 \mu \mathrm{g})$, tobramycin $(30 \mu \mathrm{g})$, erythromycin $(15 \mu \mathrm{g}), \quad$ clindamycin $(10 \mu \mathrm{g})$ oxolinic acid $(2 \mu \mathrm{g})$, ciprofloxacin $(5 \mu \mathrm{g})$, ofloxacin $(5 \mu \mathrm{g})$, tetracycline $(30 \mu \mathrm{g})$ and chloramphenicol $(30 \mu \mathrm{g})$ (Oxoid, England). Briefly, each $V$. alginolyticus isolate was streaked onto Mueller-Hinton agar (Oxoid, England), then the antibiotic disks were dispensed on the plate and incubated at $22^{\circ} \mathrm{C}$ for 24 hours. Inhibition zones diameters were measured and interpreted according to the CLSI (2006).

\section{6- Pathogenicity test:}

A total of 20 acclimated healthy $R$. haffara fish with an average body weight of $60 \pm 5 \mathrm{~g}$ were obtained from the National Institute of Oceanography and
Fisheries, Hurghada, Egypt and were used for the experimental challenge. Fish were divided into 2 equal groups; the $1^{\text {st }}$ group was injected $\mathrm{I} / \mathrm{P}$ with $0.1 \mathrm{ml}$ of $V$. alginolyticus suspension $\left(3 \times 10^{7} \mathrm{CFU}\right)$ while the $2^{\text {nd }}$ group was injected I/P with $0.1 \mathrm{ml}$ of sterile saline where used as control. The two groups were closely observed daily for 2 weeks and the clinical signs, mortalities and PM lesions were recorded. Recovery and identification of $V$. alginolyticus from liver, spleen and kidney of the challenged fish were conducted.

\section{RESULTS}

\section{1- Clinical and post-mortem examination:}

The clinical examination of the naturally infected fishes revealed septicemic picture and PM lesions including lethargy and sluggish movement, scale loss and congestion on the abdomen, fins congestion (Photo 1) and rot especially tail fin (Photo 2), hemorrhages on the body (Photo 3) and ulcers on the head and body (Photo 4). The PM lesions were 
in the form of accumulation of ascitic fluid in the abdominal cavity and intestinal distention with clear fluid
(Photo 5), paleness or congestion of liver and congestion of spleen, kidney and muscles (Photo 6).

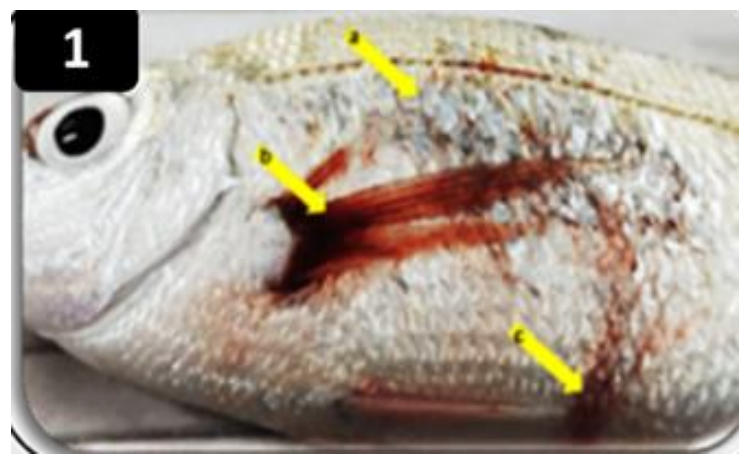

Photo (1): R. haffara showed hemorrhages, scale loss and fin congestion.

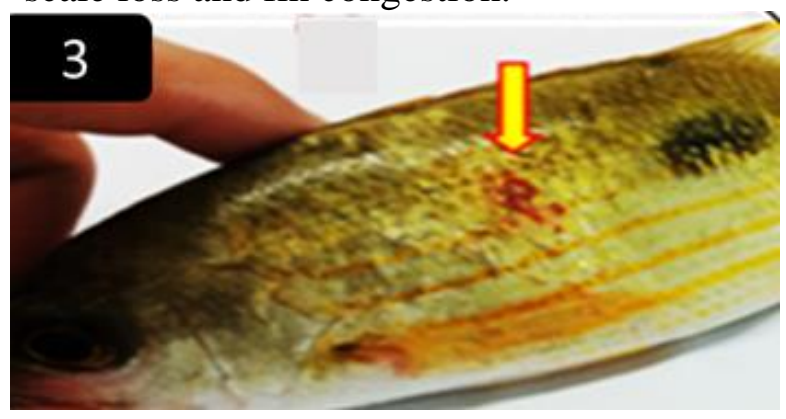

Photo (3): L. ehrenbergii showed hemorrhage on the body.

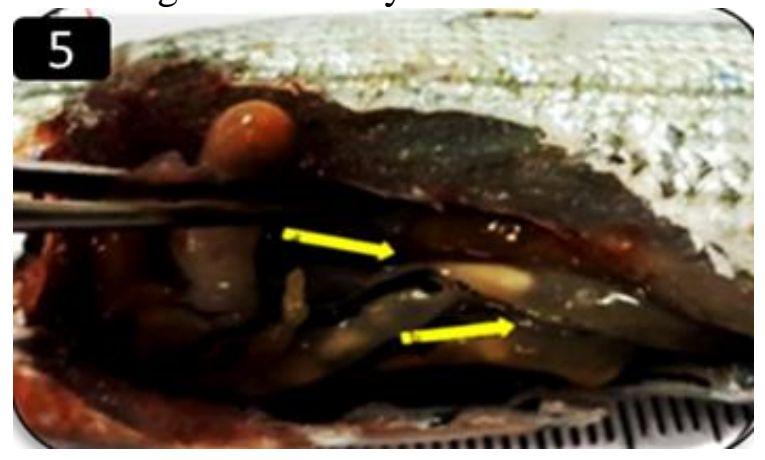

Photo (5): $R$. haffara showed distended intestine filled with fluids.

2- Bacterial isolation, phenotypic identification and prevalence of $V$. alginolyticus infection among the examined fishes:

Based on the morphological and biochemical characteristics of the isolated bacteria, $64 \mathrm{~V}$. alginolyticus

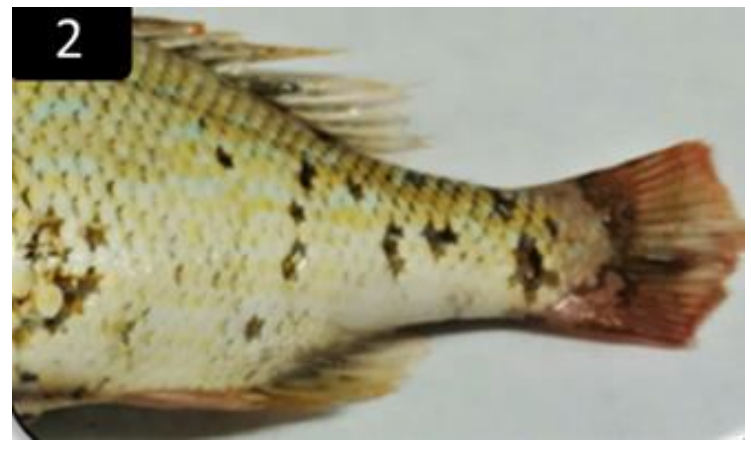

Photo (2): L. ehrenbergii showed tail fin rot.

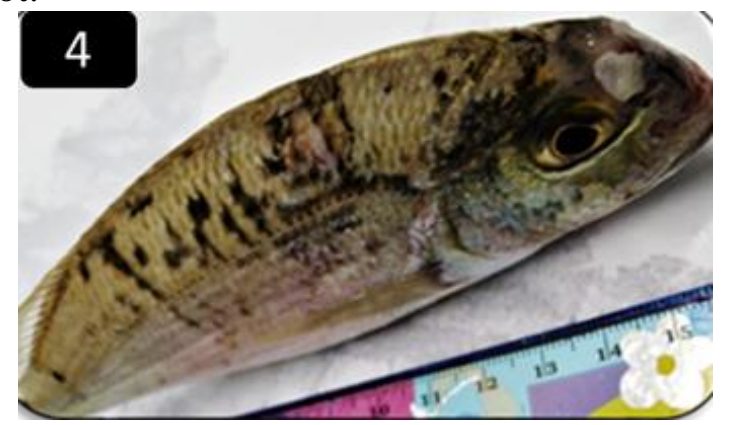

Photo (4): L. borbonicus showed ulcers and hemorrhages on the head and body.

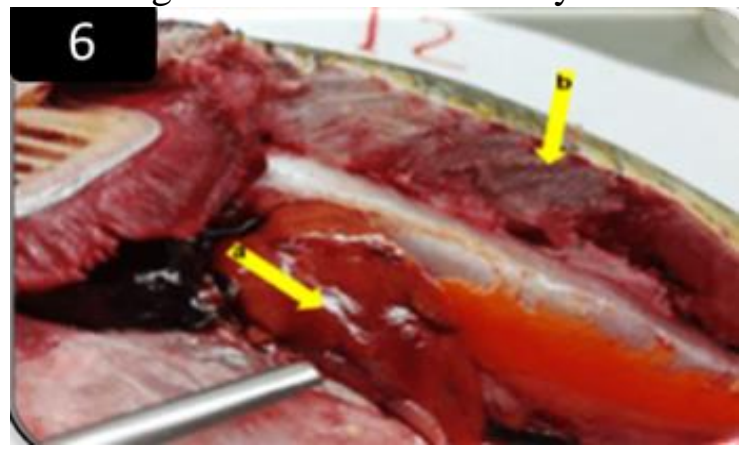

Photo (6): L. ehrenbergii showed liver and muscles congestion.

isolates were obtained and identified phenotypically from the internal organs of the examined fishes. Prevalence of $V$. alginolyticus infection among the examined fishes was summarized in Table (2). 
Table 2: Prevalence of $V$. alginolyticus infection among the examined Red Sea fishes.

\begin{tabular}{cccc}
\hline \multirow{2}{*}{ Fish species } & Number of the & \multicolumn{2}{c}{ V. alginolyticus } \\
\cline { 3 - 4 } & examined fish & $\begin{array}{c}\text { Number of the } \\
\text { infected fish }\end{array}$ & $\begin{array}{c}\text { Percentage of } \\
\text { infection (\%) }\end{array}$ \\
\hline L. ehrenbergii & 30 & 8 & 26.7 \\
\hline L. borbonicus & 30 & 6 & 20 \\
\hline S. rivulatus & 30 & 19 & 63.3 \\
\hline R. haffara & 30 & 11 & 36.7 \\
\hline S. ghobban & 30 & 7 & 23.3 \\
\hline C. lunulatus & 30 & 13 & 43.3 \\
\hline Total & 180 & 64 & 35.6 \\
\hline
\end{tabular}

On TSA, $V$. alginolyticus isolates produced creamy colored, moist, rounded colonies with regular edges and in some cases adhered strongly to the media. On TCBS, it produced yellow colonies. On microscopical examination, $V$. alginolyticus was motile gram-negative short bacilli. They were biochemically homogeneous where all the isolates showed the same biochemical characteristics illustrated in the Table (3) and Fig. (1).

Table 3: Biochemical characteristics of $V$. alginolyticus isolates.

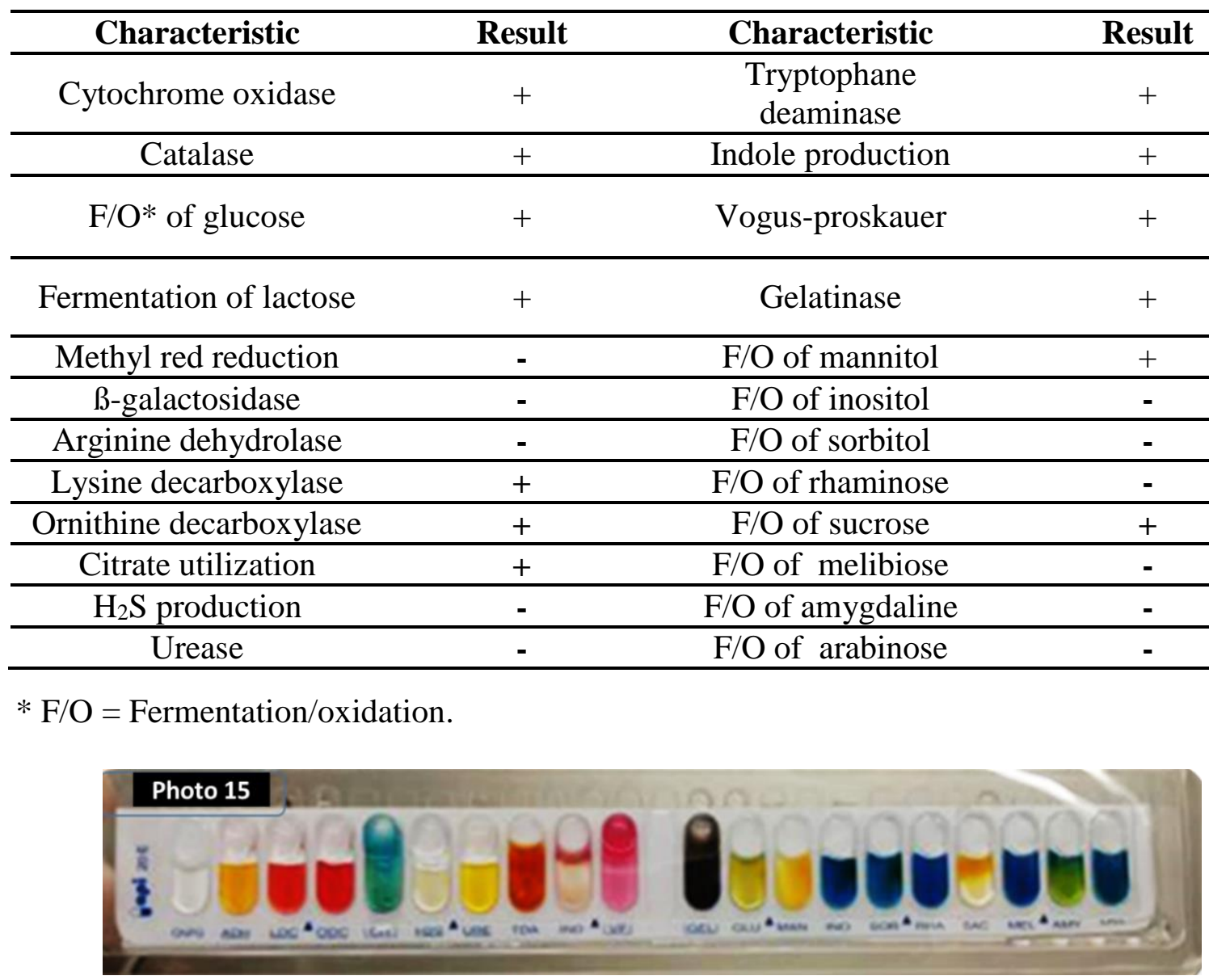

Fig. (1): Results of characterization of V. alginolyticus by API 20E strip. 
3- 16S rRNA gene sequence analysis:

On comparison the nucleotide sequence of $16 \mathrm{~S}$ rRNA gene of our $V$. alginolyticus isolate MR-C17 with the nucleotide sequence of 16S rRNA genes of Vibrio spp. stored in GenBank databases, it showed identity of 99.79 to
$100 \%$ with sequences of the present isolates as illustrated in Table (4) and Fig. (2). Sequence of $16 \mathrm{~S}$ rRNA gene of our $V$. alginolyticus isolate MR-C17 was deposited into NCBI and assigned accession no. MW790239.

Table 4: Similarity values of $16 \mathrm{~S}$ rRNA gene sequence of $V$. alginolyticus MR-C17 and $16 \mathrm{~S}$ rRNA gene sequences of the other maximum identical related species.

\begin{tabular}{ccc}
\hline Isolate & GenBank accession no & $\begin{array}{c}\text { Identity percentage with } \\
\text { V. alginolyticus MR-C17 }\end{array}$ \\
\hline V. alginolyticus YWO-72 & MT368030.1 & $100 \%$ \\
\hline V. alginolyticus NBRC $15630^{\mathrm{T}}$ & KT 989844.1 & $99.93 \%$ \\
\hline V. neocalendonicus NC $470^{\mathrm{T}}$ & NR118258.1 & $99.93 \%$ \\
\hline V. harveyi 5-52 & MW015820.1 & $99.93 \%$ \\
\hline V. parahemolyticus ATCC $17802^{\mathrm{T}}$ & MN519533.1 & $99.79 \%$ \\
\hline
\end{tabular}

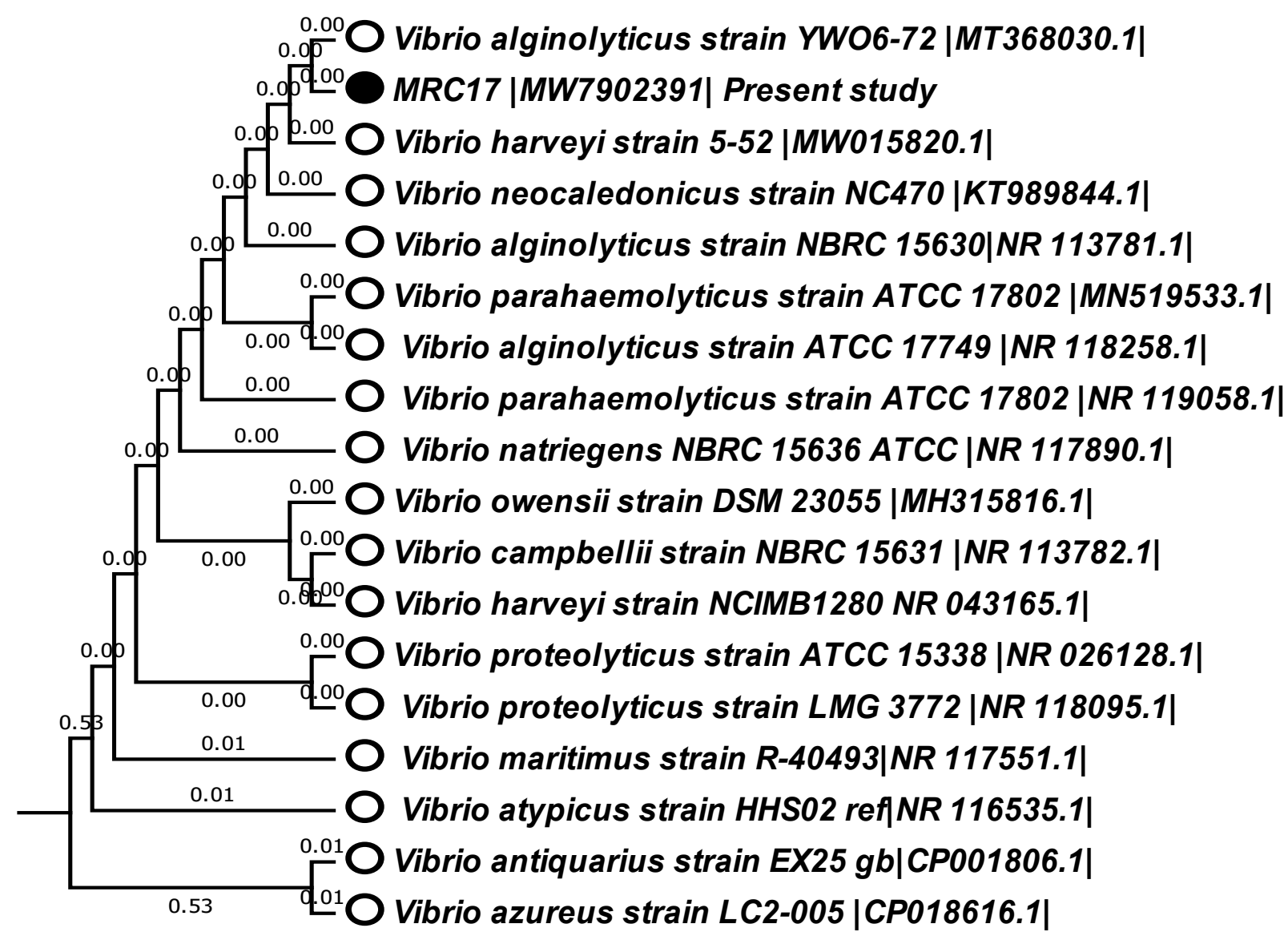

Fig. (2): Phylogenetic tree showing evolutionary relationship of $V$. alginolyticus MR-C17 with the other Vibrio species on basis of 16S rRNA gene sequences evolutionary distance. 


\section{4- Antimicrobial susceptibility testing:}

Antimicrobial susceptibility testing of $V$. alginolyticus isolates to the used antibiotics in this study revealed that the isolates were sensitive to chloramphenicol, tetracycline, ciprofloxacin and ofloxacin and resistant to ampicillin, cephalothin, amikacin, streptomycin, cefotaxime, erythromycin, oxolonic acid, amoxicillin/clavulanic acid, tobramycin and clindamycin.

\section{5- Pathogenicity test:}

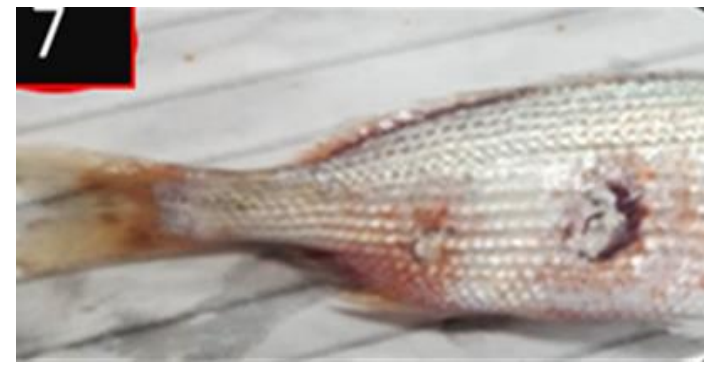

Photo (7): Deep skin ulcer and hemorrhagic ulcer on the body.

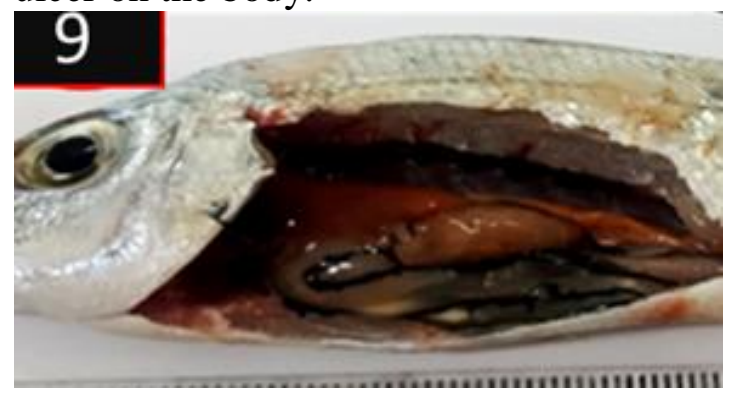

Photo (9): Intestinal distension with fluid and liver congestion.

\section{DISCUSSION}

$V$. alginolyticus is considered one of the most important pathogens of marine fishes inducing not only marine fish Vibriosis but also serious food poisoning in human after consuming undercooked seafood products (Qiang et al., 2006 and Sadok et al., 2013).

In this study, the clinical signs of $V$. alginolyticus infection were hemorrhages
The experimentally challenged $R$. haffara with $V$. alginolyticus exhibited signs of hemorrhages on the body, skin ulcer and hemorrhagic frayed tail fin (Photo 7), corneal opacity (Photo 8), congestion of the liver (Photo 9) and abdominal distension (Photo 10). The mortality rate was $70 \%$ at end of the first week and reached $80 \%$ at end of the second week. $V$. alginolyticus was re-isolated and identified from the internal organs of the experimentally-infected fish.

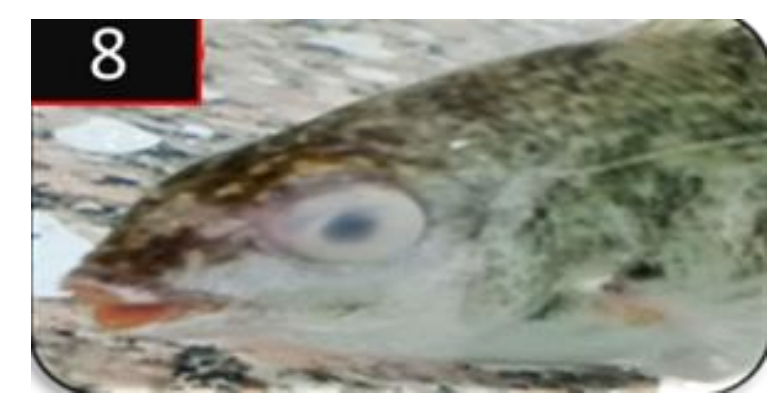

Photo (8): Eye opacity.

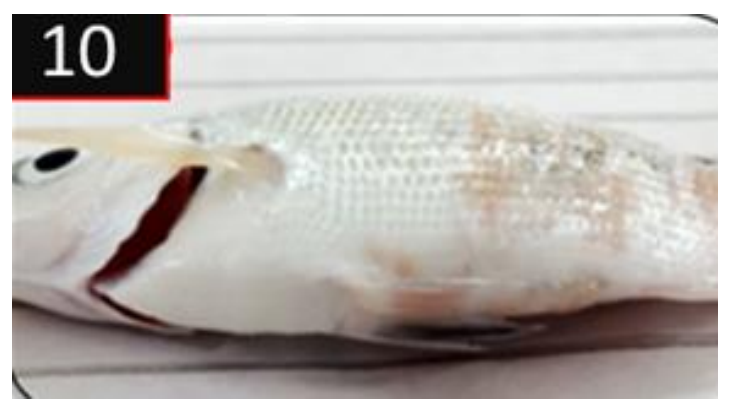

Photo (10): Abdominal distension and hemorrhage on the body.

on the body and at bases of the fins, scale loss and skin ulcers. The PM lesions were accumulation of ascitic fluid in the abdominal cavity, swollen intestine and congestion or paleness of the internal organs especially liver. These findings were in agreement with thoes of Abd ElGalil and Hashem (2012), Abd El Tawab et al. (2018) and El-Sayed et al. (2019) who reported similar clinical signs and 
PM lesion in $V$. alginolyticus infected fishes. All fishes infected with $V$. alginolyticus manifested frayed fins and fins rot that adversely affected the swimming activities and foraging behavior of the diseased fish leading to loss of condition and weakness (Martins et al., 2012; Kujur and Parganiha, 2013 and Khalil and Emeash, 2018). The clinical signs and PM lesions of the diseased fishes may be attributed to the pathogen's extracellular products such as proteases, lipases, hemolysin, collagenase and hyaluronidase released during the infection that involved in lesions development, these products were secreted by $V$. alginolyticus (Lee et al., 2003; Supansa et al., 2015 and Salamone et al., 2019). Also, the diffused hemorrhages all over the body may be attributed to elastase enzyme and hemolysin factor secreted by the pathogens and damage of the blood vessels leading to blood leakage which contributed to the hemorrhagic septicemia of the diseased fishes (Zhang and Austin 2005).

In this study and according to data illustrated in Table (2), prevalence of $V$. alginolyticus infection among the examined L. ehrenbergii, L. borbonicus, $S$. rivulatus, $R$. haffara, $S$. ghobban and C. lunulatus fishes were (26.7\%), (20\%), (63.3\%), (36.7\%), (23.3\%) and (43.3\%) respectively with a total prevalence of (35.6\%) among all the examined fish species. Abdel-Aziz et al. (2013) reported higher prevalence of $V$. alginolyticus (82.19\%) and (87.28\%) among Gilthead sea bream and European sea bass in the Egyptian coastal provinces respectively. Also, Abou ElAtta and El-Ekiaby (2012) found that prevalence of $V$. alginolyticus infection among Mugil cephalous was $40 \%$, these differences may be attributed to the different fish species, locality and sampling season.

Phenotyping is used in conjunction with serology and genotyping to identify the bacterial pathogens (Coquet et al., 2002). In this study, $V$. alginolyticus isolates were identified as $V$. alginolyticus based on the morphological and biochemical characteristics including API20E. $V$. alginolyticus isolates were motile gramnegative short bacilli and produced typical $V$. alginolyticus colonies. They were biochemically homogeneous where all the isolates were positive in catalase, cytochrome oxidase, lysine decarboxylase, ornithine decarboxylase, citrate utilization, indole production, Voges-Proskauer, tryptophane deaminase and gelatinase tests and in fermentation of glucose, sucrose, mannitol and lactose while they were negative in $\beta$ galactosidase, arginine dihydrolase, methyl red reduction, $\mathrm{H}_{2} \mathrm{~S}$ production and urease tests and in fermentation of inositol, sorbitol, rhaminose, melibiose, amygdaline and arabinose. These results were in agreement with thoes of Abd ElGalil and Hashem (2012) and Beleneva et al. (2004) who recorded similar biochemical reactions with $V$. alginolyticus isolated from marine fishes.

Accuracy of bacterial diseases diagnosis plays a great role in their successful control and treatment and in protecting fish production industry from the bacterial diseases outbreaks which cause high economic losses and may cause human health hazards (Buller et al., 2004). 16S rRNA gene sequence alongside the biochemical tests gave accurate diagnosis and identification of the bacterial pathogens in the laboratory diagnosis (Clarridge, 2004). In this study, identification of our isolates as $V$. alginolyticus was complemented and 
confirmed by $16 \mathrm{~S}$ rRNA sequence analysis. As shown in Table (4) and Fig. (2), on comparing 16S rRNA gene sequence of our $V$. alginolyticus isolates MR-C17 with the known 16S rRNA gene sequences of Vibrio spp. isolates stored on GenBank databases, it showed similarity of 99.79 to $100 \%$ with them and showed similarity of $100 \%$ with $V$. alginolyticus $\quad$ YWO-72 ${ }^{\mathrm{T}} \quad$ (GenBank accession no MT368030.1). This finding was similar to that of Cao et al. (2018).

Regarding the results of antimicrobial susceptibility test, $V$. alginolyticus isolates were sensitive to chloramphenicol, tetracycline, ciprofloxacin and ofloxacin. Our findings were in accordance with the findings of Ardic and Ozyurt (2004), Abd El-Galil and Hashem (2012), Younes et al. (2016), Rameshkumar et al. (2017), Elsayed et al. (2018) and Arafah et al. (2019) who reported that $V$. alginolyticus were sensitive to tetracycline, ciprofloxacin and chloramphenicol. The variations in results of antibiotic sensitivity tests may be due to the dramatic antimicrobial resistance growth that makes an urgent need to discover new effective antimicrobial agents (Abdallah and Abdalla, 2018).

Results of pathogenicity test in this study proved that our $V$. alginolyticus isolate was pathogenic to $R$. haffara. Similar clinical signs and PM lesions were observed in the naturally and experimentally infected $R$. haffara with $80.0 \%$ mortalities in the experimentally infected fish. Koch's postulates were also fulfilled in this experiment where $V$. alginolyticus was re-isolated and identified from the internal organs of the experimentally infected fish. These findings agreed with those of Abd ElGalil and Hashem (2012) who observed similar clinical signs and PM lesions in Gomphosus caeruleus experimentally infected with $V$. alginolyticus.

\section{CONCLUSION}

The present study reported Vibriosis among six species of Red Sea fishes. The isolates were identified as $V$. alginolyticus by the morphological and biochemical characteristics in addition to sequencing of 16s rRNA gene which confirmed this identification and which was deposited into NCBI as MR-C17 (GenBank accession no. MW790239). V. alginolyticus isolates were pathogenic to $R$. haffara and sensitive to chloramphenicol, tetracycline, ciprofloxacin and ofloxacin.

\section{AUTHOR'S CONTRIBUTION}

All authors contributed equally in this work. They read and approved the final manuscript.

\section{CONFLICT OF INTEREST}

The authors declare that they have no conflict of interest.

\section{REFERENCES}

Abdallah, E.M. and Abdalla, W.E. (2018): Black pepper fruit (Piper nigrum L.) as antibacterial agent: A mini-review. Journal of Bacteriology and Mycology, 6(2): 141-145.

Abdel-Aziz, M.; Eissa, A.E.; Hanna, M. and Abou Okada, M. (2013): Identifying some pathogenic Vibrio/Photobacterium species during mass mortalities of cultured Gilthead seabream (Sparus aurata) and European seabass (Dicentrarchus labrax) from some 
Egyptian coastal provinces. International Journal of Veterinary Science and Medicine, 1(2): 87-95. Abd El-Galil, M.A.A. and Hashem, M.M. (2012): First isolation of Vibrio alginolyticus from ornamental bird wrasse fish (Gomphosus caeruleus) of the Red Sea in Egypt. Journal of Fisheries and Aquatic Science, 7(6), 461.

Abd El Tawab, A.; Ibrahim A.M. and Sittien, A. (2018): Phenotypic and genotypic characterization of Vibrio species isolated from marine fishes. Benha Veterinary Medical Journal, 34 (1): 79-93.

American Veterinary Medical Association (A.A.V.M) (2007): AVMA guidelines on euthanasia.

Abou El-Atta, E.M. and El-Ekiaby, T.W. (2012): Prevalence of bacterial infection associated with Caligus infestation in cultured Mugil cephalus with trial to control. Abbassa International Journal of Aquaculture, 5 (1): 415-440.

Arafah, M.E.; Hashem, M.; Omar, A.G. and Haridy, M. (2019): An outbreak of Vibrio alginolyticus infection in aquarium-maintained dark-spotted (Himantura uarnak) and Tahitian (H. fai) stingrays. Egyptian Journal of Aquatic Research, 45:153-155.

Ardic, N. and Ozyurt, M. (2004): Case report: Otitis due to Vibrio alginolyticus. Mikrobiyol Bul., 38(1-2): 145-148.

Austin, B. and Austin, D.A. (1987): Bacterial Fish Pathogens: Disease in Farmed and Wild $1^{\text {st }}$ Ed. Ellis Horwood Limited.

Austin, B. and Austin, D.A. (2007): Characteristics of the diseases. Bacterial Fish Pathogens: Diseases of Farmed and Wild Fish, $4^{\text {th }} \mathrm{Ed}$, 15-46.
Beleneva, I.A.; Maslennikova, E.F. and Magarlamov, T.Y. (2004): Physiological and biochemical characteristics of the halophilic bacteria Vibrio parahaemolyticus and $V$. alginolyticus isolated from marine invertebrates of Peter the Great Bay, Sea of Japan. Russian Journal of Marine Biology, 30(2): 96-100.

Bogorodsky, S.V. and Randall, J.E. (2019): Endemic Fishes of the Red Sea. In: Oceanographic and Biological Aspects of the Red Sea, Rasul, N.M.A. and Stewart, I.C.F. (eds.), $\quad 1^{\text {st }} \quad \mathrm{Ed}, \quad$ Springer Oceanography, Switzerland.

Buller, N.B. (2004): Bacteria from fish and other aquatic animals: A practical identification manual. $1^{\text {st }}$ Ed, Cabi Publishing.

Cao, J.; Zhang, J.; Ma, L.; Li, J.; Zhang, $W$. and $L i, J$. (2018): Identification of fish source Vibrio alginolyticus and evaluation of its bacterial ghosts vaccine immune effects. Microbiologyopen, 7 (3): 1-11.

Clarridge, J.E. (2004): Impact of $16 \mathrm{~S}$ rRNA gene sequence analysis for identification of bacteria on clinical microbiology and infectious diseases. Clinical microbiology reviews, 17, 840-862.

CLSI (2006): Methods for Antimicrobial Broth Dilution and Disk Diffusion Susceptibility Testing of Bacteria Isolated From Aquatic Animals. $2^{\text {nd }}$ Ed. CLSI guideline VET03. Wayne, PA: Clinical and Laboratory Standards Institute.

Coquet, L.; Cosette, P.; Quillet, L.; Petit, $F$.; Junter, G. and Jouenne, T. (2002): Occurrence and phenotypic characterization of $Y$. ruckeri strains with biofilm-forming capacity in a rainbow trout farm. Appl. Environ. Microb., 68:470- 
475.

Costinar, L.; Herman, V.; Pascu, C.; Marcu, A.; Marcu, A. and Faur B. (2010): Isolation and characterization of Vibrio alginolyticus and Pasteurella spp. from Siberian Sturgeon (Acipenser Baerii). Lucrări Stiinłifice Medicină Veterinară, Vol. Xliii Timisoara.

El-Sayed, M.; Algammal, A.; AbouelAtta, M.; Mabrok, M. and Emam, A. (2019): Pathogenicity, genetic typing, and antibiotic sensitivity of Vibrio alginolyticus isolated from Oreochromis niloticus and Tilapia zillii. Rev. Med. Vet, 170: 80-86.

Elsayed, M.; Essawy, M.; Shabana, I.; Abou El-Atta, M. and EL-Banna, N. (2018): Studies on bacterial pathogens in some marine fishes in EL-Mansoura, Egypt. Amer. J. Agric. Biol. Sci, 13 (1): 9-15.

$F A O, F$. (2012): agriculture organization of the United Nations. FAO Statistical Yearbook.

Frank, J.A.; Reich, C.I.; Sharma, S.; Weisbaum, J.S.; Wilson, B.A. and Olsen, G.J. (2008): Critical evaluation of two primers commonly used for amplification of bacterial 16S rRNA genes. Applied and Environmental Microbiology, 74 (8): 2461-2470.

Hassan, H.B.A.; Mohamed, E.A.; Abdel Fatah H.Y. and Mohamed. K.A. (2019): An analytical economic study of fish production in Egypt. Middle East Journal of Agriculture Research, 8 (1): 139-152.

Holt, J.G.; Krieg, N.R.; Sneath, P.H.; Staley, J.T. and Williams, S.T. (1994): Bergey's Manual of Determinative Bacteriology. $9^{\text {th }} \mathrm{Ed}$., Lippincott Williams \& Wilkins, USA.

Khalil, F. and Emeash, H. (2018):
Behavior and stereotypies of Nile Tilapia (Oreochromis niloticus) in response to experimental infection with Aeromonas hydrophila. Aquatic Sciences and Engineering, 33 (4): 124-130.

Kujur, P. and Parganiha, A. (2013): Social interaction in fish: A Brief Review. Journal of Ravishankar University-B, 24 (26): 26-34.

Kumar, S.; Stecher, G. and Tamura, K. (2016): MEGA7: molecular evolutionary genetics analysis version 7.0 for bigger datasets. Molecular Biology and Evolution, 33 (7): 1870-1874.

Lee, E.Y.; Lee, T.K.; Park, T.S.; Oh, S.H.; Park, K.H.; Figueras, M.J. and Chang, C.L. (2003): Misidentification of Aeromonas veronii biovar sobria as Vibrio alginolyticus by the Vitek system. Letters in Applied Microbiology, 37 (4): 349-353.

Liu, P.; Lin, J.; Hsiao, P. and Lee, K. (2004): Isolation and characterization of pathogenic Vibrio alginolyticus from diseased cobia Rachycentron canadum. Journal of Basic Microbiology, 44 (1): 23-28.

Mancuso, M.; Genovese, M.; Guerrera, M.C.; Casella, G.; Genovese, L.; Piccolo, G. and Maricchiolo, G. (2015): First episode of vibriosis in wild specimens of Pagellus bogaraveo (Brünnich, 1768) in the Mediterranean Sea. Cah. Biol. Mar, 56: 355-361.

Martins, C.I.M.; Galhardo, L.; Noble, C.; Damsgård, B.; Spedicato, M.T.; Zupa, W.; Beauchaud, M.; Kulczykowska, E.; Massabuau, J.C. and Carter, T. (2012): Behavioural indicators of welfare in farmed fish. Fish Physiology and Biochemistry, 38 (1): 17-41. 
Mohanty, B.R. and Sahoo, P.K. (2007): Edwardsiellosis in fish: a brief review. Journal of Biosciences, 32 (3): 1331-1344.

Noga, E.J. (1996): Fish Diseases: Diagnosis and Treatment. $1^{\text {st }} \mathrm{Ed}$, Mosby Yearbook, Inc. Weslin Industrial Drive.

Polz, M.F. and Cavanaugh, C.M. (1998): Bias in template-to-product ratios in multitemplate PCR. Applied and Environmental Microbiology, 64 (10): 3724-3730.

Qiang, C; Qing, Y. and Shen M.A. (2006): Progress on pathogenicity research of Vibrio alginolyticus. Ann. Rev. Marine Sci., 30: 83-89.

Rameshkumar, P.; Nazar, A.K.A.; Pradeep, M.A.; Kalidas, C.; Jayakumar, R.; Tamilmani, G.; Sakthivel, M.; Samal, A.K., Sirajudeen, S. and Venkatesan, V. (2017): Isolation and characterization of pathogenic Vibrio alginolyticus from sea cage cultured cobia (Rachycentron canadum (Linnaeus 1766) in India. Letters in Applied Microbiology, 65 (5): 423-430.

Sadok, K.; Mejdi, S; Nourhen, S. and Amin, B. (2013): Phenotyping characterization and RAPD fingerprinting of Vibrio parahaemolyticus and Vibrio alginolyticus isolated during Tunisian fish farm outbreaks. Folia Microbiol., 58 (1): 17-26.
Salamone, M.; Nicosia, A.; Ghersi, G. and Tagliavia, M. (2019): Vibrio proteases for biomedical applications: modulating the proteolytic secretome of $V$. alginolyticus and $V$. parahaemolyticus for improved enzymes production. Microorganisms, 7 (10), 387.

Schäperclaus, W. (1992): Fish diseases (Vol. 1). CRC Press. Pp. 120-122.

Sangeetha, G.; Rajeshwari, S. and Venckatesh, R. (2012): Green synthesized $\mathrm{ZnO}$ nanoparticles against bacterial and fungal pathogens. Progress in Natural Science: Materials International, 22 (6): 693-700.

Supansa, B.; Natthawan, S. and Varaporn, V. (2015): Extracellular enzymes produced by Vibrio alginolyticus isolated from environments and diseased aquatic animals. Procedia Chemistry. 18: 12-17.

Younes, A.M.; Fares, M.O.; Gaafar, A.Y. and Mohamed, L.A. (2016): Isolation of Vibrio alginolyticus and Vibrio vulnificus strains from cultured Oreochromis niloticus around Qarun Lake, Egypt. Global Veterinaria, 16 (1): 1-5.

Zhang, X. and Austin, B. (2005): Haemolysins in Vibrio species. Journal of Applied Microbiology, 98 (5): 1011-1019. 


\title{
دراسات عن الإصابة بالفيبريو الجينوليتيكاس فى بعض أسماك البحر الأحمر بالغردقة
}

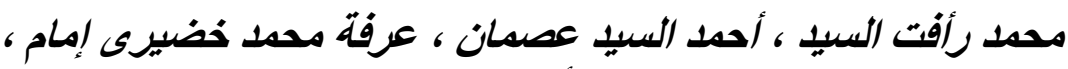

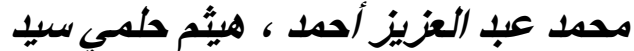

E-mail: abdelgali11997@yahoo.com Assiut University web-site: www.aun.edu.eg

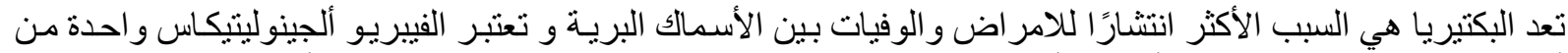

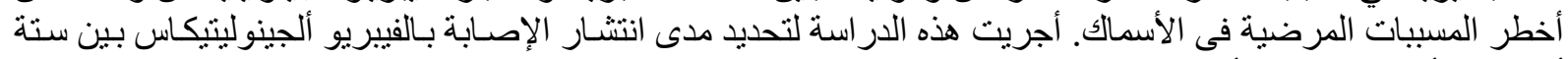

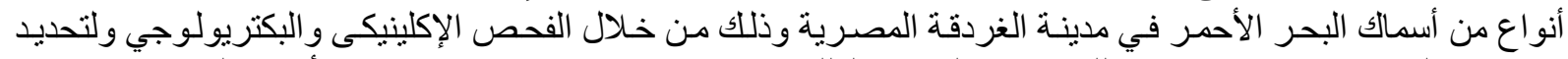

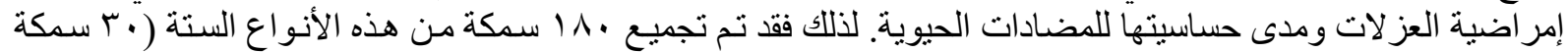

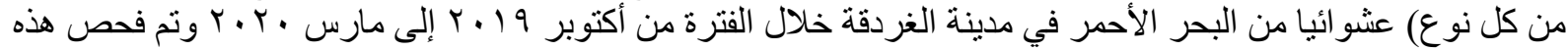

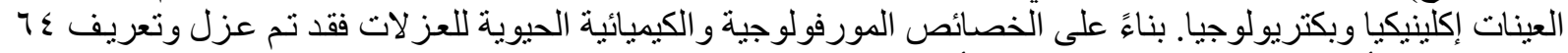

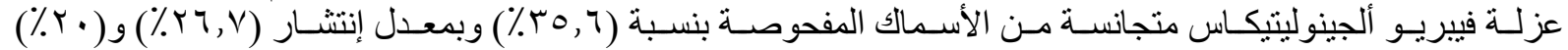

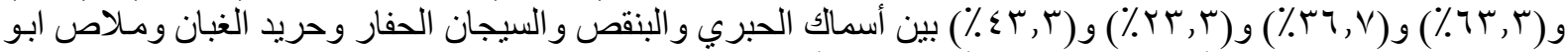

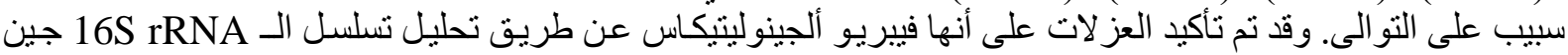

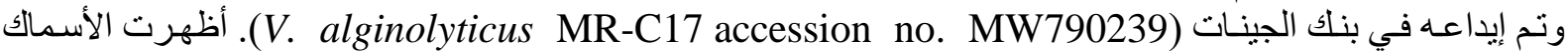

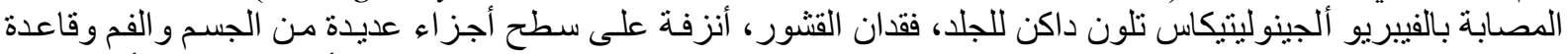

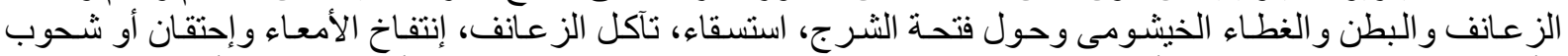

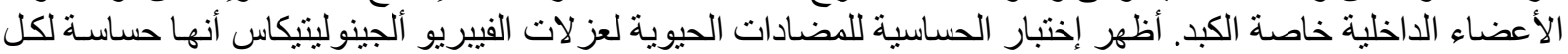

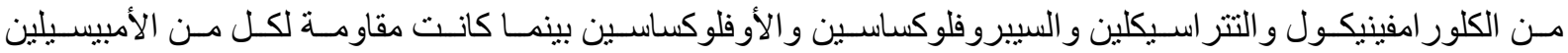

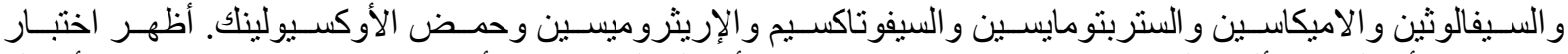

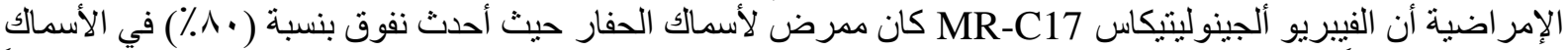

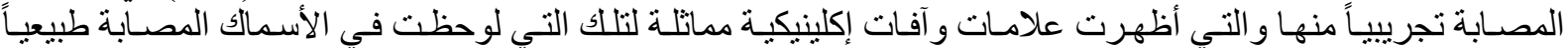
بالفيبريو ألجينوليتيكاس. 